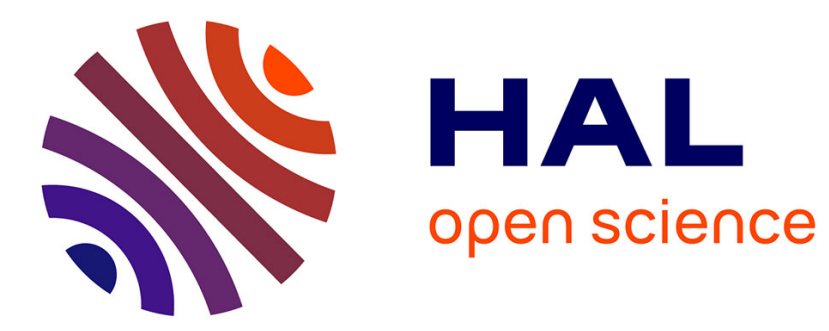

\title{
Processing thermal barrier coatings via sol-gel route: crack network control and durability
}

Fabien Blas, Florence Ansart, Philippe Lours, Jean-Pierre Bonino, Sandrine Duluard, Vanessa Vidal, Lisa Pin, Guillaume Pujol, Luiza Bonin

\section{- To cite this version:}

Fabien Blas, Florence Ansart, Philippe Lours, Jean-Pierre Bonino, Sandrine Duluard, et al.. Processing thermal barrier coatings via sol-gel route: crack network control and durability. Surface and Coatings Technology, 2018, 334, pp.71-77. 10.1016/j.surfcoat.2017.11.008 . hal-01637109

\author{
HAL Id: hal-01637109 \\ https://hal.science/hal-01637109
}

Submitted on 20 May 2019

HAL is a multi-disciplinary open access archive for the deposit and dissemination of scientific research documents, whether they are published or not. The documents may come from teaching and research institutions in France or abroad, or from public or private research centers.
L'archive ouverte pluridisciplinaire HAL, est destinée au dépôt et à la diffusion de documents scientifiques de niveau recherche, publiés ou non, émanant des établissements d'enseignement et de recherche français ou étrangers, des laboratoires publics ou privés. 


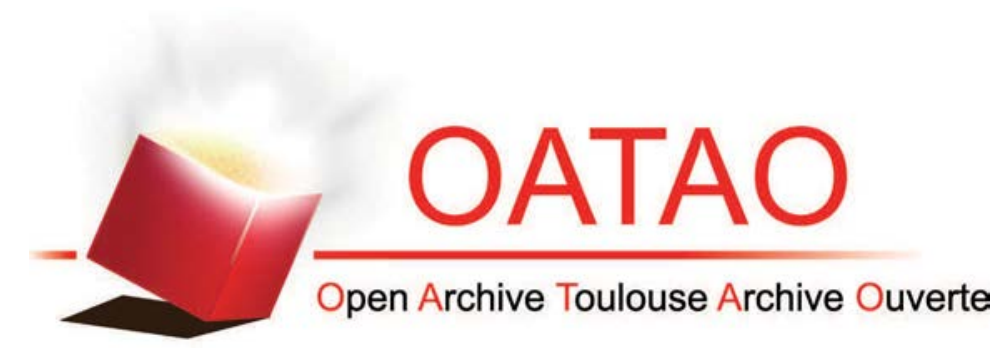

\section{Open Archive Toulouse Archive Ouverte (OATAO)}

OATAO is an open access repository that collects the work of some Toulouse researchers and makes it freely available over the web where possible.

This is an author's version published in: https://oatao.univ-toulouse.fr/23784

Official URL : https://doi.org/10.1016/j.surfcoat.2017.11.008

\section{To cite this version :}

Blas, Fabien $\leftrightarrows$ and Ansart, Florence $\fallingdotseq$ and Lours, Philippe and Bonino, Jean-Pierre Duluard, Sandrine Nathalie $\leftrightarrows$ and Vidal, Vanessa and Pin, Lisa $\leftrightarrows$ and Pujol, Guillaume and Bonin, Luiza $\rightleftharpoons$ Processing thermal barrier coatings via sol-gel route: crack network control and durability. (2018) Surface and Coatings Technology, 334. 71-77. ISSN 0257-8972

Any correspondence concerning this service should be sent to the repository administrator: tech-oatao@listes-diff.inp-toulouse.fr 


\title{
Processing thermal barrier coatings via sol-gel route: Crack network control and durability
}

\author{
Fabien Blas ${ }^{\mathrm{a}, \mathrm{b}, \mathrm{c}, \mathrm{d}}$, Florence Ansart ${ }^{\mathrm{a}, \mathrm{b}}$, Philippe Lours ${ }^{\mathrm{c}, \mathrm{d}}$, Jean-Pierre Bonino ${ }^{\mathrm{a}, \mathrm{b}}$, \\ Sandrine Duluard ${ }^{\mathrm{a}, \mathrm{b}, *}$, Vanessa Vidal ${ }^{\mathrm{c}, \mathrm{d}}$, Lisa Pin ${ }^{\mathrm{a}, \mathrm{b}}$, Guillaume Pujol ${ }^{\mathrm{a}, \mathrm{b}}$, Luiza Bonin ${ }^{\mathrm{a}, \mathrm{b}}$ \\ a CIRIMAT, Université de Toulouse, CNRS, INPT, UPS, Université Toulouse 3 Paul Sabatier, 118 route de Narbonne, F-31062 Toulouse Cedex 9, France \\ ${ }^{\mathrm{b}}$ Université de Toulouse, CNRS, INPT, UPS, 118 route de Narbonne, 31062 Toulouse, France \\ ${ }^{c}$ ICA (Institut Clément Ader), Université de Toulouse, INSA, UPS, Mines Albi, ISAE, Campus Jarlard, 81013 Albi, France \\ ${ }^{\mathrm{d}}$ Université de Toulouse, INSA, UPS, Mines Albi, ISAE; Campus Jarlard, 81013 Albi, France
}

\section{A R T I C L E I N F O}

Keywords:

Thermal barrier coatings

Sol-gel

Cracked network

Reinforcement

Cyclic oxidation

\begin{abstract}
A B S T R A C T
Thermal barrier coatings (TBC) processed by sol-gel route are deposited onto NiPtAl bond coated superalloy substrates. A crack microstructure, if well controlled, is adequate to get satisfactory thermo-mechanical behaviour when the TBC is cyclically oxidized. This paper deals with the adjustment of the properties of the microcracked network which is inherent to the process by changing the formulation of the sol and by adding a reinforcement step. The objective is to reduce the size and depth of the surface cracks network. This network controls the release of thermo-mechanical stress in the layers and reduces detrimental propagation of cracks that could result in the spallation of the coatings during engine operation. Several physico-chemical characterizations were performed, associated to image analyses to (i) evaluate the cracks distribution (depth, length and width), in the case of two dispersants, and (ii) to estimate their influence on the performances of TBC systems. Characterizations by cyclic oxidation were carried out using a cyclic oxidation instrumented rig to monitor on a real time basis the crack propagation and spallation. Correlations between the cracked network parameters and the lifetime of the TBC are proposed in this paper.
\end{abstract}

\section{Introduction}

Thermal barrier coatings (TBC) are used as thermal insulators in aircraft jet engines and more specifically as a protection for turbine blades engine. Service temperatures have been increased for some years and these temperatures are sometimes higher than the degradation temperature of the used superalloys. In these conditions, the role of TBCs is to maintain or even to increase the lifetime of such complex turbine blade systems [1]. TBCs systems are made up of a single crystal nickel-based superalloy, which ensures good mechanical stability. The bondcoat, deposited onto the superalloy, plays an important role in the accommodation of lateral thermomechanical constraints. It also plays the role of a reservoir of aluminium allowing the formation of a socalled Thermal Grown Oxide (TGO) on its surface. Finally, the topcoat is a protective ceramic layer of yttria-stabilized zirconia. This ceramic has the great advantage of having a low thermal conductivity, which allows to enhance the achievable thermal gradient up to $1{ }^{\circ} \mathrm{C}$ per $\mu \mathrm{m}$.

Nowadays, two processes are conventionally used in industry to elaborate TBCs. The first is the Electron Beam Physical Vapour
Deposition leading typically to a columnar structure coating [2]. This technique is used to coat parts subjected to high thermomechanical constraints since lateral movement of column remains possible to sustain in-service stresses. The second process is the Air Plasma Spraying which generates a lamellar structure parallel to the substrate $[3,4]$ and shows particularly good thermal insulation properties. The control of vertical and horizontal cracks development in Air Plasma Sprayed thermal barrier coatings have been studied in order to improve thermomechanical stress accommodation [5].

One of the key-issue is to develop an innovative low-cost process to elaborate thermal barrier coatings with equivalent or better performances than that of thermal barrier coatings deposited using the above standard industrial processes. To tackle this problem, several methods can be investigated such as electrodeposition [6] or sol-gel route, a technique which has been developed over the last few years for TBC. Fenech et al. prepared YSZ:RE (Rare Earth RE $=$ La, Sm, Er) by sol-gel route and demonstrated the impact of doping level on the particle size [7]. Sniezewski et al. optimized the manufacturing route by changing the formulation to avoid the presence of aggregates [8], and improved

\footnotetext{
* Corresponding author.

E-mail address: duluard@chimie.ups-tlse.fr (S. Duluard).
} 
the durability under cyclic oxidation as well as under controlled temperature gradient cycling [9]. The works of Pin et al. were dedicated to the control of the crack network formation [10] and reinforcement by dip-coating or spray-coating [11]. The latest results obtained are very promising [12] since TBCs elaborated by the sol-gel route achieved 1485 cycles under cyclic oxidation $\left(1 \mathrm{~h}\right.$ at $1100{ }^{\circ} \mathrm{C}$ and $5 \mathrm{~min}$ of cooling) with no detrimental damage and no extensive spallation.

The key experimental technique to monitor possible spallation and address overall lifetime of thermal barrier coatings is undoubtedly the cyclic oxidation test. Indeed, at the beginning of the development of TBCs elaborated by the sol gel route, preliminary results obtained using this technique were well below expectation (lifetime lower than 40 cycles). The commonly considered specification, is a number of cycles to failure of 500 or higher (corresponding to $<20 \%$ of the surface spalled off). The result for lifetime being unsatisfactory, some investigations, in previous works [12] focussed on the filling of additional ceramics in the bottom of the initially formed cracks to further reinforce the (micro-cracks) network and/or to modify the scale of this microcracked network. So, as presented by Pin et al. reinforcement by spray coating was successfully performed. This technique consists in spraying a fluid sol to partially fill in and consequently reinforce the micro-crack network. Nevertheless these promising results can only be reached if a double step process is carried out: i) deposit and thermal treatment of the TBC and generation of a primary cracks network and ii) reinforcement of the micro-cracks network by partially filling with additional ceramics within the cracks so as to reduce the size of the secondary cracks network. This two-step processing route is obviously not optimized in terms of manufacturing time and ease of preparation considerations.

This is the reason why the challenge of the study presented in this paper is to process in only one step new thermal barrier coatings by investigating a new dispersant able to directly generate a primary finer cracks network, stiff enough to satisfactorily sustain high number of oxidation cycles.

Regarding the elaboration step of the coating, an initial sequence consists in covering the superalloy with an yttria-stabilized zirconia composite sol by successive dip-coatings at a controlled speed. In this study, for the sol formulation, several dispersants are used in the composite medium. The phosphate ester Beycostat C213 dispersant (CECA), previously used to process thermal barrier coatings [12] and now subject to environmental restrictions, is the reference. The Polyvinylpyrrolidone (PVP) compound (BASF) with $\mathrm{M}_{\mathrm{w}}=3500 \mathrm{~g} / \mathrm{mol}$, as well as commercial Hypermer KD1 and KD2 (Croda) dispersants often used in a broad range of technical applications (cosmetics, adhesives, inks, textiles and fibers...), are chosen as alternative dispersants.

Then, a heat treatment is required to generate and control a microcrack network. For the durability test, samples are submitted to cyclic oxidation with the following parameters for each cycle: exposure at $1100{ }^{\circ} \mathrm{C}$ for $1 \mathrm{~h}$ followed by 5 min cooling. The evolution of the microcrack network is then recorded by charge coupled device (CCD) camera upon each cooling sequence.

The complete methodology is the following:

i) Identification of new dispersants \& formulation of the dispersions

ii) Processing of the TBC

iii) Spray-coating reinforcement step if applicable

iv) Comparison with the reference material (made with C213 dispersant): cracks network morphologies and cyclic oxidation performances

\section{Materials and methods}

\subsection{Elaboration of the TBCs by sol-gel route}

\subsubsection{Substrate pre-treatment}

The substrates used for depositing YSZ are discs of $25 \mathrm{~mm}( \pm 5)$ in diameter made of AM1 Ni-based superalloys covered with (Ni,Pt)Al bond-coats. They were provided by SAFRAN Group. Samples were sandblasted with corundum 220 meshes at 2.5 bars for $10 \mathrm{~s}$. Then, they were pre-treated using acetone cleaning followed by an ultrasonic cleaning in 1-propanol. Substrates were then pre-oxidized at $950{ }^{\circ} \mathrm{C}$ for $2 \mathrm{~h}$ at $5 \times 10^{-4}$ mbar $\mathrm{P}_{\mathrm{O} 2}$ synthetic air to favour the growth of a thin, dense and adherent alpha alumina layer [13]. This Thermal Grown Oxide (TGO) thickness was $<1 \mu \mathrm{m}$ after pre-oxidation.

\subsubsection{Sol-gel deposition process}

To elaborate TBCs, the first step consists in preparing an aerogel YSZ powder by the sol-gel route from zirconium (IV) propoxide $\mathrm{Zr}(\mathrm{OPr})_{4}$ (Aldrich) and yttrium (III) nitrate hexahydrate (Acros Organics) [14]. Acetylacetone (AcAc) is used as a complexing agent to reduce the hydrolysis rate of zirconium alkoxide [15], and the solvent is 1-propanol. Molar ratios between AcAc and $\mathrm{Zr}(\mathrm{OPr})_{4}$ and between $\mathrm{H}_{2} \mathrm{O}$ and $\mathrm{Zr}$ $(\mathrm{OPr})_{4}$ are respectively 0.8 and 9.5. Zirconium concentration is kept constant at $0.5 \mathrm{~mol} \cdot \mathrm{L}^{-1}$. Then, supercritical drying of the propanol at $270{ }^{\circ} \mathrm{C}$ for $1 \mathrm{~h}$ is performed so as to obtain an aerogel microstructure. To complete the processing, a heat treatment at $700{ }^{\circ} \mathrm{C}$ is carried out to remove organics. Finally, grinding for $1 \mathrm{~h}$ at 350 round per minute is required to obtain a YSZ powder at $9,7 \%_{\mathrm{mol}} \mathrm{YO}_{1.5}$ with submicronic aggregates constituted large particles $(20-30 \mathrm{~nm})$.

In each case, the protocol is the same either for the C213 (a phosphate ester, CECA), the Hypermer KD1 (polyester polyamine condensation polymer, CRODA) and the KD2 or the PVP (polyvinylpyrrolidone, $\mathrm{Mw}=3500 \mathrm{~g} / \mathrm{mol}$, BASF) dispersants. Only the weight percentage of dispersant is different. Indeed, a previous rheological study showed that $10 \mathrm{wt} \%$ (compared to the weight of the solvent) for Beycostat C213, $15 \mathrm{wt} \%$ for KD1, $10 \mathrm{wt} \%$ for $\mathrm{KD} 2$ and $1 \mathrm{wt} \%$ for PVP were the best conditions. The required amount of dispersant is dissolved in 1-propanol and a $20 \mathrm{wt} \%$ of a YSZ sol with Acac/Zr $(\mathrm{OPr})_{4}=1.2, \mathrm{H}_{2} \mathrm{O} / \mathrm{Zr}(\mathrm{OPr})_{4}=9.5$ and $\mathrm{Zr}(\mathrm{OPr}) 4$ concentration of $0.5 \mathrm{~mol} \cdot \mathrm{L}^{-1}$ is added. Each composite sol is then loaded with $50 \mathrm{wt} \%$ of aerogel powder. The criteria, here, is the obtention of a stable dispersion, which is assessed by the absence of a hysteresis in the evolution of the viscosity with increasing and decreasing shear rate. Then, the superalloy substrates are dipped into the slurry and withdrawn at a controlled rate $\left(250 \mathrm{~mm} \cdot \mathrm{min}^{-1}\right)$ to shape the coatings. Following each dip, the layer is dried at $50^{\circ} \mathrm{C}$ for $5 \mathrm{~min}$. These operations are repeated until the required TBC thickness is reached (about $150 \mu \mathrm{m}$ ). Specimens are sintered at $1100 \mathrm{C}$ for $2 \mathrm{~h}$ using heating and cooling rates of $50{ }^{\circ} \mathrm{C} /$ $\mathrm{h}$ to generate a controlled micro-cracks network and release thermomechanical constraints due to sintering.

The reinforcement step consists in spraying a sol with $\mathrm{x}$ wt $\%$ of YSZ commercial powder (TOSOH 8Y), $20 \mathrm{wt} \%$ of the YSZ sol, 4\%wt ultrapure water and propanol. The sequence is a six steps process consisting of two steps with $\mathrm{x}=20 \mathrm{wt} \%$ and four steps with $\mathrm{x}=10 \mathrm{wt} \%$. The slurry is sprayed at the vertical on top of the TBC coating, and the pressure and displacement rate of the spray nozzle are controlled. The sample is dried for $5 \mathrm{~min}$ between each spraying step.

\subsubsection{Choice of a new dispersant}

The reference dispersant is a commercial product: the Beycostat C213, which is a phosphoric ester composed of $50 \%$ monoester and $50 \%$ diester. This dispersant presents a combination of electrostatic and steric repulsion forces. To investigate substitutes to Beycostat C213, several dispersants with similar dispersion mechanism (i.e. electrostatic and steric hindrance) were investigated. Hypermer KD1 (polyester polyamine condensation polymer), Hypermer KD2, polyvinylpyrrolidone PVP $M_{w} 3500$ and PVP $M_{w} 55,000$ were considered, due to the presence of groups with similar functions as, for example in PVP, a pyrrolidone cycle as anchoring group and polymeric chains for steric hindrance. Their ability to dissolve and to process stable dispersions in the alcohol based media were also taken into account. In order to preserve a similar protocol, starting precursors used for the 


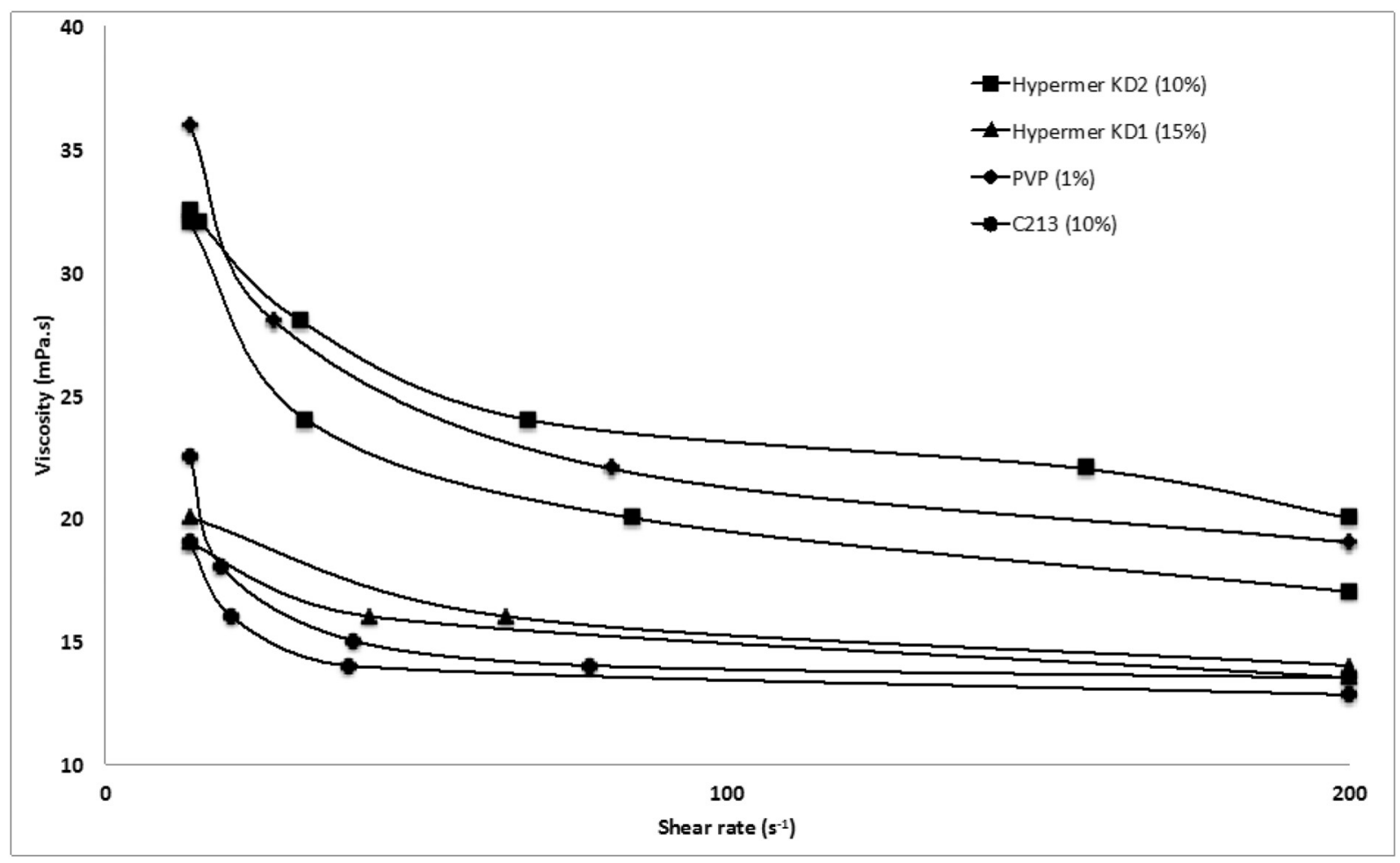

Fig. 1. Evolution of the viscosity versus the shear rate for each dispersant.

formulation of the composite sol (previously described) remained unchanged: 1-propanol, acetylacetone, ultra-pure water, zirconium propoxide, yttrium nitrate hexahydrate. The criterion to define the optimal percentages for each dispersant (based on their ability to disperse), is relative to their rheological properties (Fig. 1). The chosen dispersant must have a viscosity approaching that of the C213 dispersant which is the case of all the selected dispersant $\left(10-25 \mathrm{mPa} \cdot \mathrm{s}\right.$ at $\left.100 \mathrm{~s}^{-1}\right)$. Another parameter to take into account is the stability of the suspension, that was evaluated from the hysteresis area between the values of viscosities taken with increasing shear rates and those taken with decreasing shear rates (the lowest the hysteresis the highest the stability).

Following this preliminary step, the chosen dispersant as a function of the viscosity criterion, was PVP $3500 \mathrm{M}_{\mathrm{w}}$ corresponding to $1 \%_{\mathrm{wt}}$ because of the lack of hysteresis, which means that the composite sol is stable. The absence of hysteresis is also a signature of the lack of large aggregates that could be broken at high shear rates, thus smaller aggregation is expected in PVP dispersion as compared to C213 dispersions. PVP dispersant is made up of a long carbon chain and a vinyl group on the ramifications. These groups allow a steric hindrance in the solution that causes the particles to repel each other. Note that PVP percentage is ten times lower than for the C213 (10\%wt) so that the particle volume fraction is higher for PVP based material as compared to C213 ones. According to $[16,17]$ works, the increase in particle volume fraction will have a huge impact on material fracture toughness since elastic modulus and energy release for the creation of crack surface depend on the particle volume fraction to the fourth power. In order to evaluate such effect PVP and C213 were selected for developing the thermal barrier coatings investigated in this paper.

\subsection{Characterizations techniques}

Rheological measurements are performed at room temperature $\left(20^{\circ} \mathrm{C}\right)$ with an ANTON PAAR Physica MCR 301 viscosimeter. The samples surface is characterized by optical microscopy using a numerical device KEYENCE VHX-1000 to compare the global and general surface characteristics of microstructures and cracked networks obtained from each dispersant. Then, an image analysis using APHELION (ADCIS) software is performed to determine the density of micro-cracks, the mean length and mean width of cracks as well as the mean size of cells.

Surface morphological characteristics have also been analysed through a micro-topography approach (ALTISURF 520-Altimet Device) by evaluating the roughness parameters and extracting the cracks profiles, giving parameters such as depth, amplitude... (Altimap software). The surface profile of samples was measured using contactless surface microtopography so as to determine various roughness $\left(R_{a}, R_{s k}\right)$ and morphological parameters (cracks shape and depth).

Thermal barrier coatings were cyclically oxidized within a dedicated instrumented rig allowing to monitor, using various types of optical means, the evolution of the sample surface during the cooling phases [9]. Typical cycles include $5 \mathrm{~min}$ heating, $1 \mathrm{~h}$ holding at high temperature and $5 \mathrm{~min}$ cooling down to room temperature.

\section{Results and discussion}

\subsection{Cracks parameters for C213 and PVP based thermal barriers}

After elaboration, TBCs are (i) characterized using image analysis of optical micrographs at an adequate magnification revealing the different individual cells and (ii) compared in terms of morphological characteristics (Fig. 2).

On Fig. 2.i, optical micrographs of the sample surface show the initial microstructure. Then, by using image analysis (Fig. 2.ii and 2.iii), different microstructural parameters were evaluated: the density of cracks, the mean size (area) of the cells ( $\mathrm{A}$ in $\mu^{2}{ }^{2}$ ), the mean length and the mean width of cracks (in $\mu \mathrm{m}$ ). Results from the image analysis of Fig. 2.iii are detailed on Fig. 3.

In Fig. 3.a, the surface fraction of cell is plotted versus the equivalent diameter $\left(\mathrm{D}=(4 \mathrm{~A} / \mathrm{\Pi})^{0.5}\right)$ of the cells, assumed, as a first approximation, to be disc-shaped.

The arithmetic average of roughness values (Ra), the skewness (Rsk) and the maximum peak-to-valley values (PV) were obtained from the 
a) $\mathrm{TBC}_{\mathrm{C} 213}$
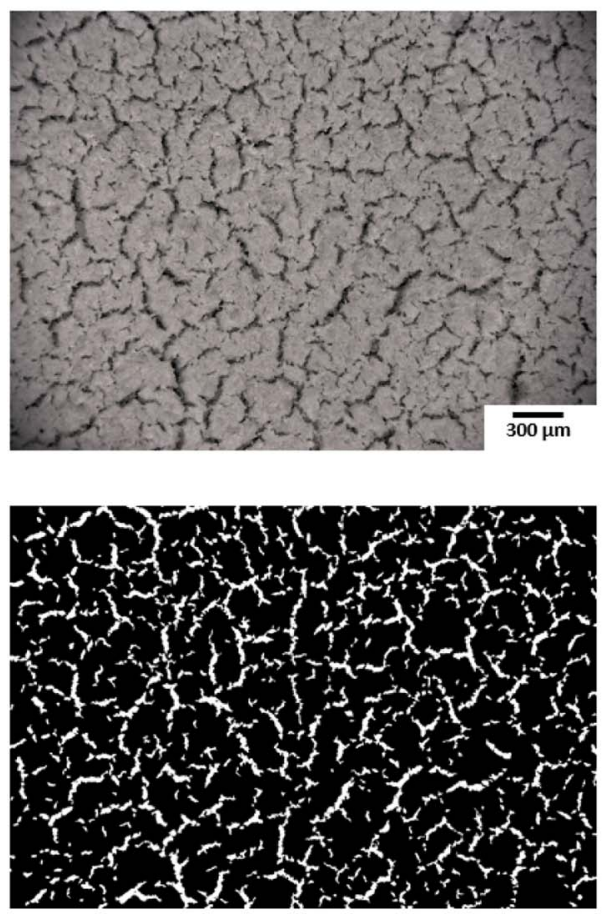

$18 \%$

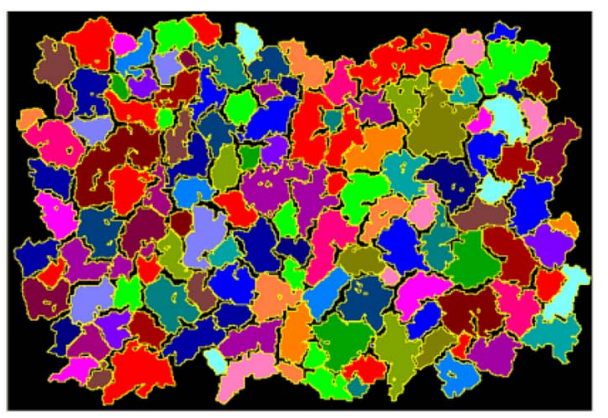

b) TBC $_{P V P}$

i)

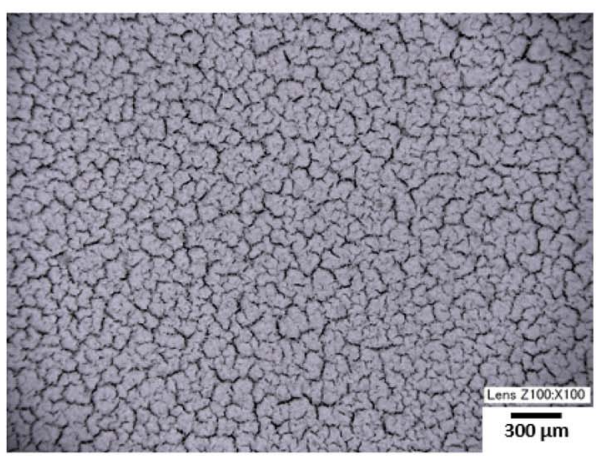

ii)

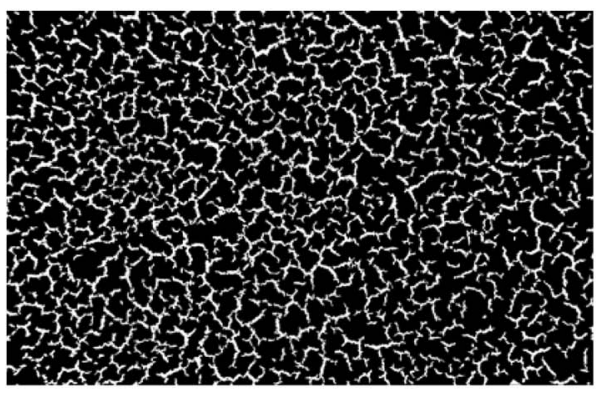

$14 \%$

iii)

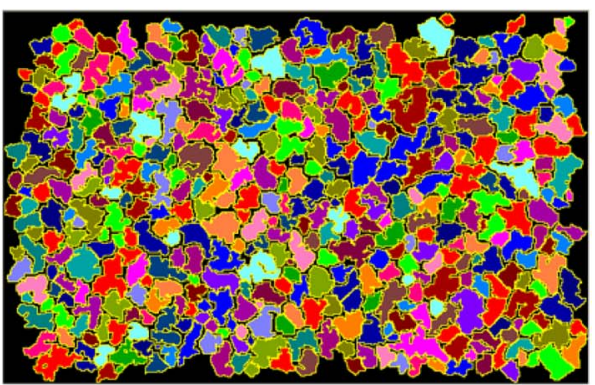

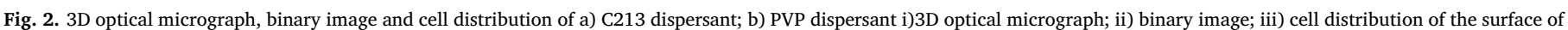
TBC.

characteristic surface profiles presented in Fig. 4.

\subsubsection{Cracks geometry}

A preliminary analysis clearly shows two different micro-crack networks, depending on the dispersant used. It is firstly noted that the crack mean density is roughly similar for both dispersants, with $14 \%$ of micro-cracks for C213 and 18\% for PVP. The overall quasi-bell curve of the fraction of cells depending on the cell diameter shows for C213 a maximum for a diameter of $170 \mu \mathrm{m}$ with a large distribution range. On the contrary in the case of PVP dispersing agent, cracks are smaller and their size distribution is notably narrower. Note that the maximum density obtained in the two cases are different: for the $\mathrm{TBC}_{\mathrm{PVP}}$, the equivalent average diameter of cells is around $100 \mu \mathrm{m}$ for a maximum cell density of $35 \%$ while for the $\mathrm{TBC}_{\mathrm{C} 213}$, the equivalent average diameter is $170 \mu \mathrm{m}$ for a maximum cell density of $13 \%$. In addition, the distribution for the $\mathrm{TBC}_{\mathrm{PVP}}$ is narrower than for the $\mathrm{TBC}_{\mathrm{C} 213}$ showing that in the case of $\mathrm{TBC}_{\mathrm{PVP}}$, the cell size and consequently the microstructure is both finer and more homogeneous.

Fig. 3.b gives information on the width of the cracks. The two distributions differ in terms of their overall shape. Indeed, the experimental values with PVP correspond to a relatively tight distribution, centred on an average width of $18 \mu \mathrm{m}$ while for the $\mathrm{TBC}_{\mathrm{C} 213}$, various peaks can be observed including a principal one centred on $28 \mu \mathrm{m}$.

As well, regarding the length of cracks (Fig. 3.c), the distribution shows several maxima, with a main contribution for a length of $75 \mu \mathrm{m}$ for thermal barriers obtained from suspensions using the C 213 dispersant. The cracks width distribution (Fig. 3.b) is more homogeneous with a satisfactory symmetry around the well-defined peak shown at $28 \mu \mathrm{m}$.

The finer and more homogeneous micro-crack networks observed when PVP is used can be related both to the quantity of dispersing agent incorporated (1\% PVP against 10\% C213) and to the narrower distribution of particles size in PVP dispersion (no hysteresis in viscosity vs. shear rates curves). Indeed, following heat treatment, the organic matter from the dispersing agent which is degraded will be much reduced in the case of PVP and will generate less material shrinkage. Moreover due to the finer microstructure with smaller defects and to the reduced volume of dispersant, the particle volume fraction is higher in PVP materials. As already explained, these conditions are expected to increase the toughness of such materials. This provides here an experimental evidence, that changing the dispersing agent has a direct effect on the micro-cracks network formed. Indeed, for roughly the 

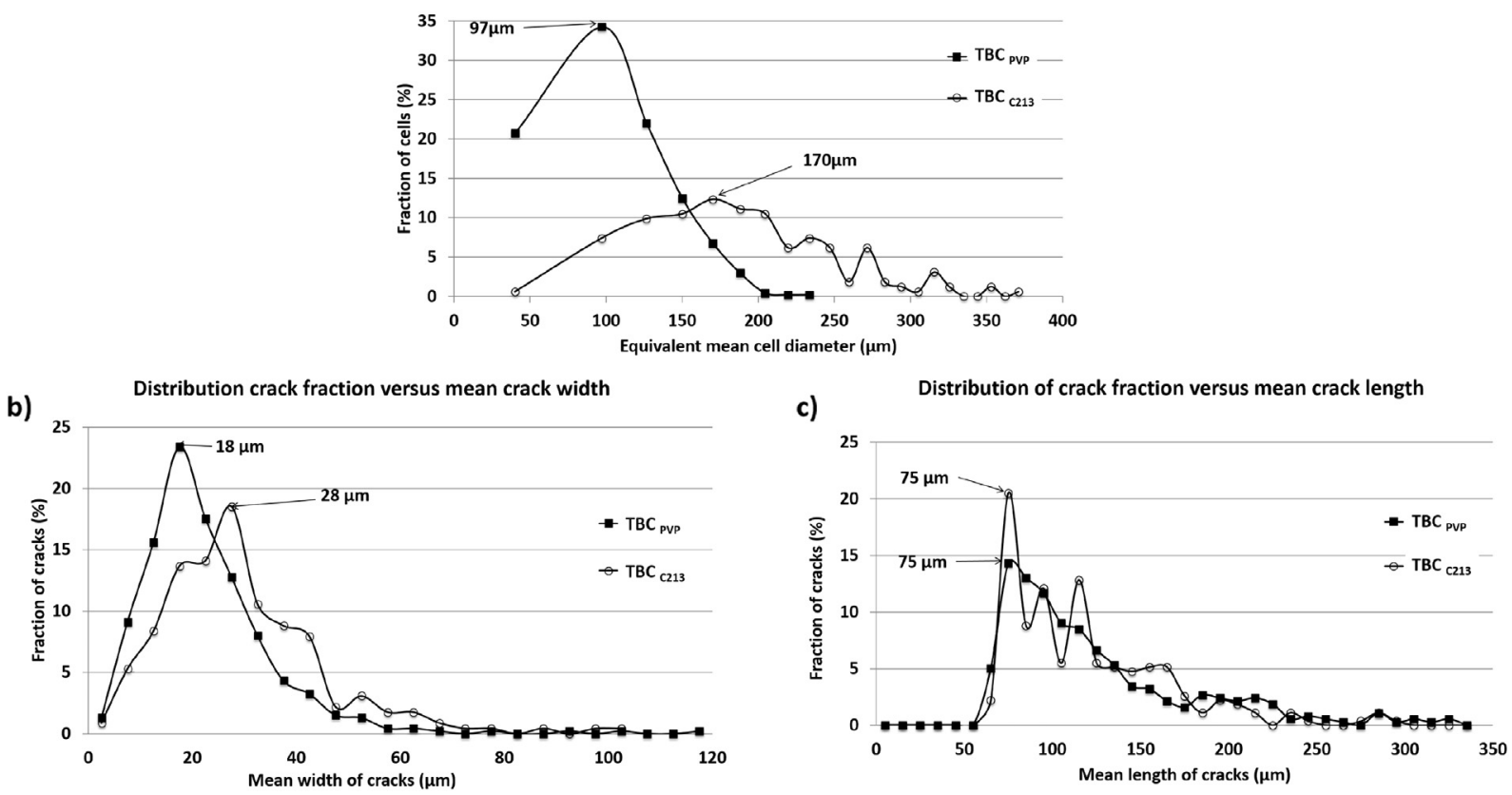

Fig. 3. Geometrical parameters of cells and cracks as a function of the dispersant.
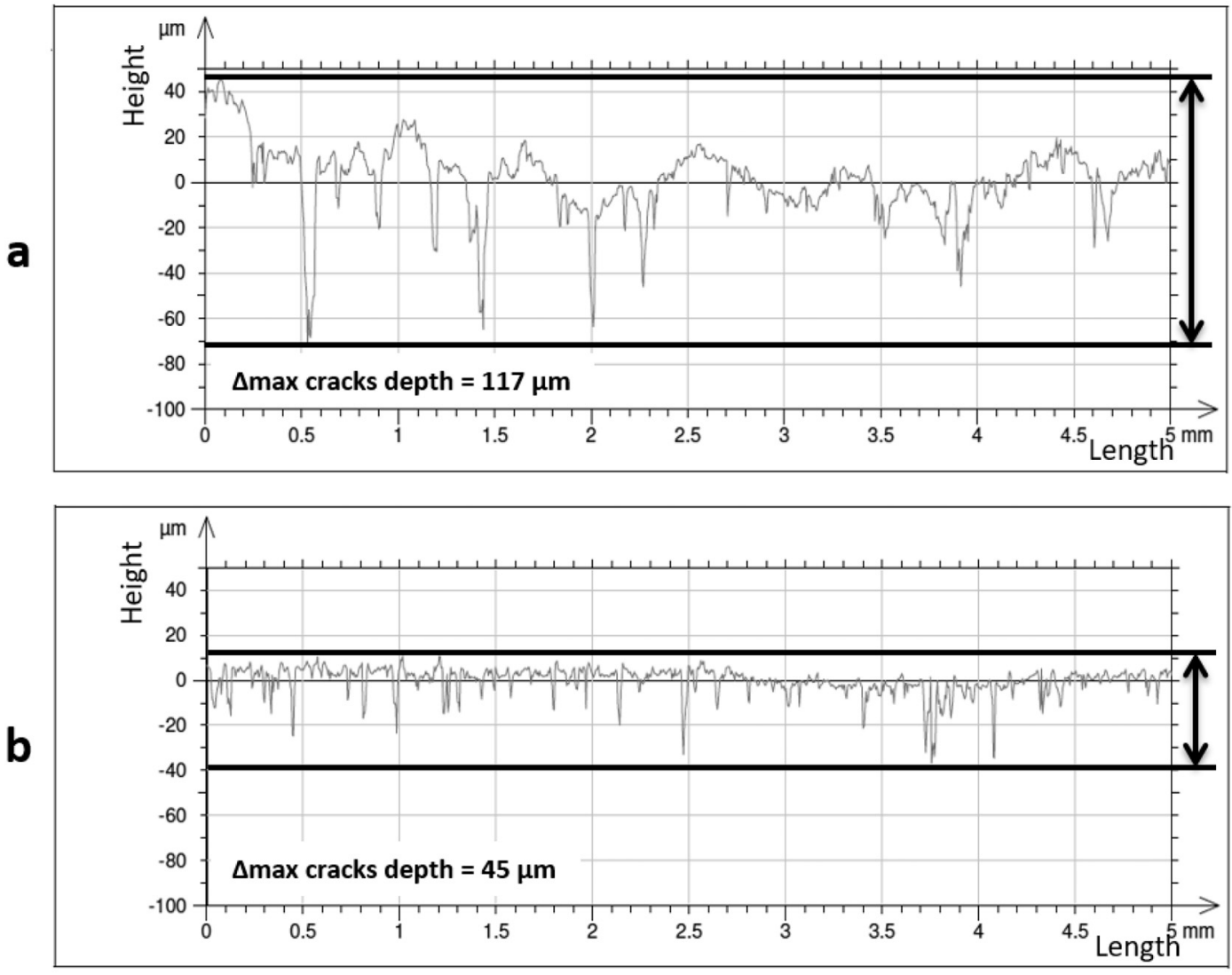

Fig. 4. Characteristic profiles for a) C213; b) PVP.

same TBC thickness (approximately $150 \mu \mathrm{m}$ ), the dimensional parameters of cells and cracks are different.

Fig. 3.c shows the distribution of the fraction of crack versus the average crack length for the two dispersing agents. The distributions are similar even if the plot for the C213 is still more irregular. The change of the dispersing agent does not have any significant influence on the average length of cracks.

\subsubsection{Topology of the cracked surface}

The characteristic topographic profiles are presented in Fig. 4 for one typical profile (five profiles were measured for each samples). Considering the profiles, the thermal barrier coatings prepared with the 
PVP dispersant exhibits narrower and less deep cracks than that formulated and shaped with C213 dispersant.

This study confirms the observation made earlier, that there is a much smoother surface topography when PVP is used. The average surface roughness (Ra) of C213 based material is twice as much as PVP ones $(7 \mu \mathrm{m}$ versus $3.5 \mu \mathrm{m})$. Peak-to-valley height is smaller in the case of PVP, which means that the cracks are much less deep than in the case of a material prepared with C213 $(117 \mu \mathrm{m})$. Moreover as already discussed the distribution of cracks is more regular in the case of PVP.

\subsubsection{Cyclic oxidation}

As previously revealed, there is a significant difference in the microstructure obtained from each formulation using the two dispersants (C213 and PVP). Consequently, the impact of these microstructural parameters on the lifetime of TBC upon cyclic oxidation has to be addressed.

During cyclic oxidation, the lifetimes of the thermal barriers elaborated with C213 and PVP dispersant are highly different. Indeed for reaching $20 \%$ surface spallation, in agreement with the current industrial specifications, sample (a), with C213 dispersant, sustains < 300 cycles while sample (b), with PVP, exhibits 1160 cycles. The expected behaviour with slower crack propagation kinetic for PVP based materials is observed.

\subsection{Effect of reinforcement by spray coating}

It has been shown in a previous study $[11,12]$, that reinforced $\mathrm{TBC}_{\mathrm{C} 213}$ (where the network of micro-cracks was filled by spraycoating), showed a promising lifetime upon cyclic oxidation. Actually, such TBC exhibited a large number of cycles to spallation, typically 1100 cycles and up to 1485 cycles, indicating that the spray-coating reinforcement is likely to enhance significantly lifetimes.

As a consequence, it is therefore of primary importance to address the effect of filling cracks by spray-coating on PVP samples, in order to check whether the cyclic oxidation lifetime is improved as well in this case.

The surface micrographs of the non-filled up sample i.e. PVP-NC (a) and the characteristic profiles of the filled up one i.e. PVP-SC (b) before and after spray-coating treatment are shown in Fig. 5.
Note that an overthickness is brought up on the sample filled by spray-coating. Of course, this global overthickness can include a preferential deposition on the sharpest areas of the coating inducing a significant increase of the Peak-to-Valley height parameter (from 45 to $90 \mu \mathrm{m})$. This overthickness is then in the range [30-40 $\mu \mathrm{m}]$. The question is now to evaluate the impact of this microstructure on the lifetime of the reinforced $\mathrm{TBC}_{\mathrm{PVP}}$. The difference in lifetime between unfilled and filled PVP samples is not very significant. First, no spallation is observed up to 1100 cycles except for the edge effects due to the dip-coating process [18]. The variation is much less pronounced than in the case of C213 formulations due to the finer morphology of the PVP coating.

As compared to EB-PVD coatings, sustaining typically around $1000-1200$ cycles, when cyclically oxidized in similar conditions, very good performances is achieved with sol-gel coatings. Indeed lifetime of the thermal barriers, reaching $>1000$ cycles for the TBC obtained with PVP, confirms that the use of PVP dispersant can beneficially replace the Beycostat C213 as dispersing agent as well as filling agent for cracks, if necessary. However, it is shown that the reinforcement of the micro-crack network is no more required in this case, the gain in lifetime being non-significant. Indeed, the process implemented in only one step is efficient enough to promote the development of reliable and competitive sol-gel thermal barrier coatings. They remain without spallation for $>1000$ oxidation cycles, in perfect agreement with required lifetime expected by engine makers.

\section{Conclusion and perspectives}

In this paper, the use of PVP as dispersant was validated in the formulation of sol-gel TBC. Effectively, it was shown that thermal barriers elaborated using PVP dispersions are made from more stable dispersions (no hysteresis in rheological curves) with lower volume fraction of dispersants (1\% for PVP based materials versus $10 \%$ for C213 ones). This leads, in PVP materials, to smaller particle sizes (less aggregation in the dispersion) and higher particle volume fraction (smaller quantities of dispersant). Both contributions are known to increase material toughness i.e. material resistance to fracture. After heat treatment the cracks development is different within PVP and C213 materials with smaller cracks width and depth for PVP. During cyclic
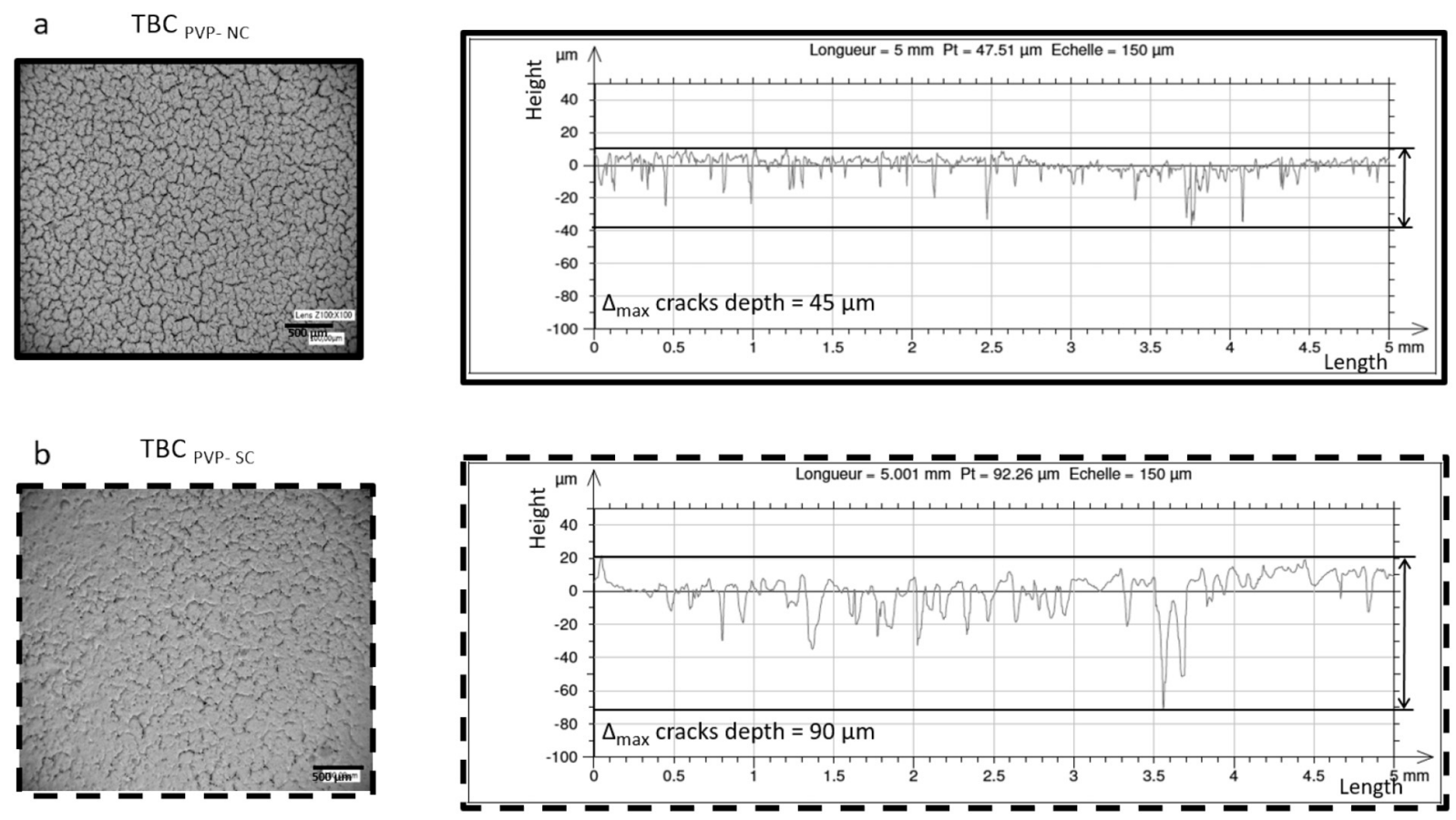

Fig. 5. Surface micrographs and characteristic profiles of the thermal barriers unfilled (TBC PVP-NC) and with the spray coating reinforcement step (TBC PVP-SC). 
oxidation tests, cracks propagation proceeds via cracks widening and deepening across the material. As expected the kinetic of cracks propagation is slower for PVP based materials and lifetime of TBC is longer ( $>1000$ cycles) than in the case of the TBC with C213 dispersant ( $<300$ cycles). Whereas reinforcement is mandatory with C213 dispersant to obtain lifetime $>1000$ cycles, such reinforcement is not necessary for PVP dispersant. Then the use of PVP dispersant represents a superior alternative to the material based on C213 dispersant. Thermal barrier coatings with $>1000$ oxidation cycles are achieved with a cost-effective simple deposition process.

\section{Acknowledgments}

This work was supported by the Ecole Doctorale Aéronautique Astronautique (ED467) (France).

\section{References}

[1] D. Stöver, C. Funke, Directions of the development of thermal barrier coatings in energy applications, J. Mater. Process. Technol. 92-93 (1999) 195-202.

[2] E. Lugscheider, C. Barimani, G. Döpper, Ceramic thermal barrier coatings deposited with the electron beam-physical vapour deposition technique, Surf. Coat. Technol. (1998) 1221-1227.

[3] D.J. Wortman, B.A. Nagaraj, E.C. Duderstadt, Thermal barrier coatings for gas turbine use, Mater. Sci. Eng. (1989) 433-440.

[4] A. Nusair Khan, J. Lu, Manipulation of air plasma spraying parameters for the production of ceramic coatings, J. Mater. Process. Technol. 209 (2009) 2508-2514.

[5] M. Karger, R. Vassen, D. Stöver, Atmospheric plasma sprayed thermal barrier coatings with high segmentation crack densities: spraying process, microstructure and thermal cycling behavior, Surf. Coat. Technol. 206 (2011) 16-23.

[6] S. Put, J. Vleugels, O. Van der Biest, Microstructural engineering of functionally graded materials by electrophoretic deposition, J. Mater. Process. Technol. 143-144 (2003) 572-577.

[7] J. Fenech, M. Dalbin, A. Barnabé, J.-P. Bonino, F. Ansart, Sol-gel processing and characterization of (RE-Y)-zirconia powders for thermal barrier coatings, Powder Technol. (2009) 480-487.

[8] J. Sniezewski, Y. Le Maoult, P. Lours, L. Pin, V. Menvie Bekale, D. Monceau, D. Oquab, J. Fenech, F. Ansart, J.-P. Bonino, Sol-gel thermal barrier coatings: optimization of the manufacturing route and durability under cyclic oxidation, Surf. Coat. Technol. (2010) 1256-1261.

[9] J. Sniezewski, Y. Le Maoult, P. Lours, Oxidation and spallation of FeCrAl alloys and thermal barrier coatings: in situ investigation under controlled temperature gradient, Mater. High Temp. (2010) 101-108.

[10] L. Pin, F. Ansart, J.-P. Bonino, Y. Le Maoult, V. Vidal, P. Lours, Processing, repairing and cyclic oxidation behaviour of sol-gel thermal barrier coatings, Surf. Coat. Technol. (2011) 1609-1614.

[11] L. Pin, F. Ansart, J.-P. Bonino, Y. Le Maoult, V. Vidal, P. Lours, Reinforced sol-gel thermal barrier coatings and their cyclic oxidation life, J. Eur. Ceram. Soc. (2013) 269-276.

[12] L. Pin, V. Vidal, F. Blas, F. Ansart, S. Duluard, J.-P. Bonino, Y. Le Maoult, P. Lours Optimized sol-gel thermal barrier coatings for long term cyclic oxidation life, Surf. Coat. Technol. (2013) 961-974.

[13] D. Monceau, F. Crabos, A. Malié, B. Pieraggi, Effects of bond-coat preoxidation and surface finish on isothermal and cyclic oxidation, high temperature corrosion and thermal shock resistance of TBC systems, Mater. Sci. Forum (2001) 607-614.

[14] M. Shane, M.L. Mecartney, Sol-gel synthesis of zirconia barrier coatings, J. Mater. Sci. (1990) 1537-1544.

[15] C. Viazzi, J.-P. Bonino, F. Ansart, Synthesis by sol-gel route and characterization of yttria stabilized zirconia coatings for thermal barrier applications, Surf. Coat. Technol. (2006) 3889-3893.

[16] K. Kendall, Agglomerate strength, Powder Metall. 31 (1988) 28.

[17] N. Birk-Braun, K. Natalie, E. Yunus, W. Rees, A. Schabel, Routh, Generation of strength in a drying film: How fracture toughness depends on dispersion properties, Phys. Rev. E 95 (2017) 022610-1/022610-6.

[18] F. Blas, La voie sol-gel pour la mise en œuvre de barrières thermiques aéronautiques, Ph-D manuscript, https://tel.archives-ouvertes.fr/tel-01492842/ document, (2016) (last access 28/07/2017). 